\title{
Is Military Justice Sentencing on the March? Should it be? And if so, Where should it Head? Court-Martial Sentencing Process, Practice, and Issues
}

James E. Baker

Georgetown University Law Center

This paper can be downloaded free of charge from:

https://scholarship.law.georgetown.edu/facpub/1468

http://ssrn.com/abstract=2574803

Fed. Sentencing Rep. Dec. 2014, at 72-87

This open-access article is brought to you by the Georgetown Law Library. Posted with permission of the author. Follow this and additional works at: https://scholarship.law.georgetown.edu/facpub 


\section{Is Military Justice Sentencing on the March? Should it be? And if so, Where should it Head? Court-Martial Sentencing Process, Practice, and Issues}

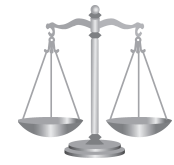

\section{JAMES E. BAKER*}

Chief Judge of the United States Court of Appeals for the Armed Forces Adjunct professor of law at Georgetown University, the University of lowa, and Washington University, St. Louis

\section{Introduction}

This is an opportune time to review sentencing in the military justice system and identify issues that warrant review. To start, military justice is in the news. A number of wartime cases placed it there, including those arising out of the Abu Ghraib prisoner abuse scandal and the first Fort Hood shootings. Concerns about sexual assault in the military have kept military justice in the news. It belongs there.

Military justice is an essential national security tool. That is because the system is designed to address both justice and good order and discipline, the capacity of a unit to accomplish its mission and do so in accordance with law. Sexual assault offenses illustrate this point. As in the civilian context, an assault in the military raises questions of justice and victim impact; however, in the military it may also have security impact. Where, for example, the perpetrator and victim are in the same unit or chain of command, the ability to accomplish the military mission as well as the morale and welfare of the unit may suffer. This dual purpose of military justice should be kept in mind as one considers the sentencing process and issues presented. ${ }^{\mathrm{I}}$

Finally, for the reasons stated above, there are multiple panels that have just reviewed, or are reviewing, the military justice system at this time. The military justice system may be on the verge of significant change, including in the area of sentencing. The Systems Response Panel, a congressionally mandated commission, was tasked with completing a review of the military justice system in the context of sexual assault. Its report was released in June 20I4. The Military Justice Review Group is a Department of Defensedirected effort to examine the Uniform Code of Military Justice from cover to cover. A legislative proposal and report from this effort are due in 2015. In addition, the Defense Legal Policy Board, Subcommittee on Military Justice in Combat Zones, produced a report in May 2013 regarding "cases of U.S. service members alleged to have caused the death, injury or abuse of non-combatants in Iraq or Afghanistan." Moreover, the Joint Service Committee, a committee of judge advocates from each of the services, reviews the Code on an annual basis and makes recommendations to the Secretary of Defense and the President on changes to the Code, including those that can be implemented by executive order. This process continues as well.

This article starts with a sketch of the military justice system to orient readers. Understanding that structure, the article then describes the sentencing process for special and general courts-martial. The article follows by identifying two core military sentencing questions: First, should commanders have authority to grant clemency? Second, should the military justice system adopt sentencing guidelines? With respect to each topic presented, the article does not attempt to answer the questions nor offer prescriptions. Rather, it seeks to identify the principal fault lines around which debate should, or will likely, fall. The article next presents "nutshell" introductions to additional sentencing matters that may warrant review as applied in the military context, including the handling of collateral matters, and the relationship between age and culpability. However, for the reasons stated, these issues are not presented in detail here.

\section{The Military Justice System}

A brief sketch of the military justice framework is helpful if one is to understand when and how sentencing issues arise and how these issues might differ from civilian practice. To start, the military justice system is directed to good order and discipline as well as to criminal justice. Thus, the Manual for Courts-Martial, which contains the Uniform Code of Military Justice (the Code), the Rules for CourtsMartial, and Military Rules of Evidences, states in its preamble that

[t]he purpose of military law is to promote justice, to assist in maintaining good order and discipline in the armed forces, to promote efficiency and effectiveness in the military establishment, and thereby to strengthen the national security of the United States.

As a result, the Code includes the authority to utilize non-judicial punishment (NJP) as well as judicial punishment and sentencing. Non-judicial punishment is authorized by Article I5 of the Code. It is generally addressed to minor disciplinary breaches, such as arriving late to formation, or perhaps to more serious disciplinary breaches by

Federal Sentencing Reporter, Vol. 27, No. 2, pp. 72-87, ISSN 1053-9867, electronic ISSN 1533-8363. (C) 2015 Vera Institute of Justice. All rights reserved. Please direct requests for permission to photocopy or reproduce article content through the University of California Press's Rights and Permissions website, http://www.ucpressjournals.com/reprintInfo.asp. DOI: I0.I525/fsr.20I4.27.2.72. 
good soldiers who warrant a second chance. NJP is meted out by unit commanders, usually at the company, battalion, and brigade level without judicial review. Commanders of naval vessels may also have this authority. Those who have served as platoon commanders will remember well standing outside the Battalion Commander's office on a Friday afternoon of a liberty weekend with "their Marines" or "their soldiers" waiting to see the Commanding Officer, who would then quickly review the evidence and pronounce sentence. Where NJP is concerned, the commander is indeed prosecutor, jury, and judge.

However, the analogy is only partly apt, because NJP is an administrative disciplinary process, not a criminal or a judicial one. As a result, the potential punishments and consequences are limited. NJP can, among other things, result in the forfeiture of pay, restriction to certain limits, and reduction in grade. From the servicemember's perspective, this may seem a lot like a criminal sentence. But NJP does not result in a criminal conviction, and in many if not most cases a junior servicemember's career can recover from the imposition of a single NJP. Moreover, if a servicemember wants to contest the facts presented at NJP or challenge the imposition of punishment, he may refuse NJP and request trial by court-martial (with limited exceptions).

The military tribunal used to adjudicate criminal accusations against U.S. servicemembers is the court-martial. Congress has established the subject matter and personal jurisdiction for trial by court-martial, and provided for three types of courts-martial: summary court-martial, special court-martial, and general court-martial. The essential differences between categories are found in the seniority of the commander authorized to convene the court-martial (the convening authority), the size and composition of the court, and the scope of permissible punishments the court is authorized to adjudge. A summary court, for example, may sentence a servicemember to no more than one month of confinement. For ease of reference, and with some exception, one might equate a summary court-martial with a misdemeanor court, and a special or general court-martial with a felony court, although the analogy is not exact. One might likewise use as a rule of thumb that a general officer must convene a general court-martial.

The Code incorporates both common law offenses, like murder and sexual assault, as well as traditional military offenses, like insubordination and desertion. The Code also incorporates federal criminal law and the law of armed conflict, and assimilates state law through the Federal Assimilative Crimes Act. Personal jurisdiction is established based on service status, rather than the nature of the crime, which means a servicemember may be charged with an offense under the Code for conduct occurring on or off base, on or off duty, and in or out of the continental United States. In some cases, there may be concurrent jurisdiction with state or federal authorities, raising the prospect that the forum selected may depend on any number of factors including comparative sentence exposure between military and local jurisdiction. Selection of a court-martial forum can also have as much to do with how prosecutorial discretion is exercised, as it does with the nature of the offense. For example, an offense like drug use might appropriately be referred to NJP or any of the three types of courtsmartial, depending on the circumstances. However, offenses like murder will invariably be referred to a general court-martial.

In the case of a special or general court-martial, a servicemember has a waivable right of appeal and mandatory review before a service Court of Criminal Appeals (e.g., the Army Court of Criminal Appeals, the Air Force Court of Criminal Appeals, etc.), provided the sentence includes one year or more of confinement or a punitive discharge (i.e., a Bad-Conduct Discharge, a Dishonorable Discharge, or in the case of commissioned officers, a Dismissal) or both.

The service Courts of Criminal Appeals (CCAs) are comprised of judge advocates designated by the senior lawyer in each service to serve as military appellate judges. ${ }^{2}$ Generally, these courts sit as panels of three. Of note, CCAs have fact-finding authority as well as the authority to review questions of law. Moreover, in addition to reviewing sentences for legal accuracy, CCAs "may affirm only such findings of guilty, and the sentence or such part or amount of the sentence, as it finds correct in law and fact and determines, on the basis of the entire record, should be approved" to ensure it is appropriate. ${ }^{3}$ This latter clause refers to what is known as sentence appropriateness review. Its exercise is discretionary and thus generally beyond subsequent appellate review, except in cases of "manifest injustice."4

From a CCA, appeal on questions of law can be taken by the Appellant or the Government to the United States Court of Appeals for the Armed Forces (USCAAF). The USCAAF "may specify or act on any issue concerning a matter of law which materially affects the rights of the parties." ${ }^{5}$ As with the lower courts in the military justice system, the All Writs Act applies to the exercise of USCAAF jurisdiction-which is to say, it is available in aid of existing jurisdiction, but cannot expand the Court's jurisdiction. In addition, jurisdictional provision is made for interlocutory government appeals to the CCAs and the USCAAF.

The USCAAF is comprised of five federal civilian judges. In theory, the Court is a manifestation of the constitutional principle of civilian control and oversight of the military in the context of the justice system. As a result, judges may not have retired from the active duty military (i.e., served twenty years or more and received a pension), in which case they would in theory be subject to recall by the Secretary of Defense. However, prior service is permitted, and consequently, retired reserve officers are permitted to serve on the Court. Moreover, in 20I4, the Court's enabling statute was amended by Congress to authorize the appointment of retired military officers as judges seven years after retiring from active duty. Thus, the question presents whether the Court, if it is composed in part or in whole of retired military officers, will be perceived as 
a civilian rather than military court by the appellants who appear before it and by the public at large.

Because the Congress created the court pursuant to its Article I legislative authority and located the Court in the Department of Defense "for administrative purposes only," rather than within the Article III judiciary, the Court is an Article I court. More precisely, it is a court created pursuant to Article I, placed in Article II, exercising what would look to most lawyers like Article III judicial powers. As with an Article III Circuit Court of Appeals, decisions of the USCAAF may be appealed to the Supreme Court of the United States. ${ }^{6}$

The Court follows the judicial guidelines of the Administrative Office of U.S. Courts, the administrative institution of the Article III judiciary. Judges of the Court are paid at the rate of Article III appellate judges. However, unlike Article III judges, they serve fifteen-year terms rather than with life tenure. (Congress is free to create such terms of office for inferior courts it sees fit to establish outside of Article III.) Further, the Court is a court of limited jurisdiction rather than general jurisdiction. Its jurisdiction is worldwide in geographic scope, but otherwise limited to appeals arising in the military justice system, and then only appeals from Special and General Courts-Martial for which a sentence of at least one-year confinement and/ or a punitive discharge is adjudged. Even here, the exercise of jurisdiction is generally discretionary, "for good cause shown." However, the Court "shall review" cases certified by the Judge Advocate General of a service or where the sentence is death.?

The USCAAF docket is comprised of questions arising under the system's primary legal and enabling documents: The Constitution (Ist, 4th, $5^{\text {th }}$ and 6th Amendments), the Code, the Rules for Court-Martial, and the Military Rules of Evidence. Whereas the sentence is reviewed in all cases submitted to a service Court of Criminal Appeals, the USCAAF entertains a small percentage of cases addressing sentencing issues. As measured solely by volume, appeals tend to address: (I) allegations of improper sentencing argument by Trial Counsel; ${ }^{8}$ (2) the scope of the rules permitting the introduction of extenuating and mitigating circumstances, e.g., rehabilitation potential; ${ }^{9}$ (3) the scope of permissible collateral matters on sentencing; ${ }^{\text {IO }}$ and, (4) questions regarding the proper calculation of sentence exposure. ${ }^{\text {II }}$ The Court does not exercise supervisory authority over inferior military courts in the military justice system. ${ }^{\mathrm{I} 2}$

Nine points of sentencing interest may help to identify distinguishing characteristics of military sentencing as well as distinctions between military and civilian practice.

First, there is no right to a jury in the military, and thus, no right to a jury of one's peers. The Supreme Court has held that Article III, section 2 of the Constitution, providing that "[t]he trial of all crimes ... shall be by jury" is inapplicable to military commissions or court-martials. ${ }^{13}$ However, a military accused does have a statutory right to elect trial by members, the rough military equivalent of a jury, or trial by military judge alone. Moreover, unlike federal civilian practice, a military accused can elect to be sentenced by members rather than the judge alone, although the forum for a contested findings case cannot be changed for sentencing. However, because sentencing in the military justice system occurs on a bifurcated basis, an accused can plead guilty before a military judge and elect members for sentencing.

As noted, juries in the military justice system are referred to as members or as Member Panels, that is, members of the court-martial. Members do not comprise a jury of one's peers or a random cross-section of military personnel. To the contrary, pursuant to Article 25 of the Code, members are not supposed to be peers, but must be senior to the accused in grade (e.g., Major, Lieutenant Colonel, Colonel) or rank (one's date of promotion within a pay-grade). Members are also selected by the convening authority based on criteria established in the Code, which include experience, education, training, length of service, and judicial temperament. An enlisted accused can elect to be tried by an enlisted panel, in which case the panel will consist of one-third enlisted personnel senior in grade to the accused as well as two-thirds commissioned officers. Otherwise, the panel will consist entirely of commissioned officers.

The size of a court-martial panel will depend on the type of court-martial, but generally a special or general courtmartial will consist of no fewer than three members or five members, respectively. With some exceptions, unanimous verdicts are not required. However, where the government seeks the death penalty, a panel must consist of no fewer than twelve members on both findings and sentence. Moreover, the determination on both findings and sentence must be unanimous.

All of which means that a servicemember's sentence can be adjudged in one of three ways: by judge alone, by officer members, or for an enlisted servicemember by one-third enlisted members and two-thirds officer members. In addition, the accused may enter into a pretrial agreement with the government that may cap the ultimate sentence approved by the convening authority, regardless of what is adjudged at court-martial. Such agreements are signed by the convening authority and approved by the military judge presiding over a court-martial. These agreements are also not disclosed to members so as not to impact the sentence that might be adjudged at trial. In the case of sentencing by military judge, the sentence limitation of such agreements is not revealed until the judge sentences the accused. Pretrial sentencing agreements are usually tied to an agreement to plead guilty. Indeed, as in civilian practice, a majority of military justice cases are resolved by plea agreement. Although central statistics are not kept, and an appellate court is a reductive location from which to make such a judgment, there is reason to believe a high majority of military justice cases are resolved by plea, although probably not as high a percentage as in civilian practice. Moreover, in military practice, plea colloquies and deals are 
subject to a more searching inquiry by the court, to ensure that they are voluntary, knowing, and accurate, than in

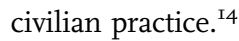

Second, courts-martial are not standing courts. They are convened by the commander in his or her capacity as a convening authority for the specific purpose of hearing a case or a series of cases. That means that if on appeal a finding or sentence is reversed and remanded with a rehearing authorized, a new court-martial must be convened. By definition that will involve new members and likely a new military judge who have not had the benefit of hearing the trial. For this reason, and others, the military Courts of Criminal Appeals are generally authorized to conduct sentence reassessments without requiring a court-martial rehearing. ${ }^{15}$ This authority may, consciously or subconsciously, prompt appellate courts to lean toward sentence reassessment rather than rehearing. ${ }^{16}$

Third, in contrast to some civilian and military justice systems overseas, neither the convening authority nor the appellate courts in the military system have the authority to increase a sentence; adjudged findings and sentences may only be approved or reduced. However, where a finding and sentence is overturned and a rehearing authorized (in other words, in the vast majority of most successful appeals), an accused may in some cases face the prospect of a higher adjudged and approved sentence. ${ }^{\text {I7 }}$

Fourth, when one talks about military discipline, military justice, or the military justice system, it is important to be precise about what one is addressing. The distinctions here are important; precision is warranted. With military justice debates, advocates sometimes talk past each other, referring to two different concepts within the same system without realizing it. This is known in legal vernacular as an "apples and oranges" problem. Take the statement, "the commander is essential to military justice." The commander is essential if one is talking about non-judicial punishment. NJP is entirely a tool of command discipline and discretion. But if one is talking about the commander's role in clemency, there is room for debate, which is explored below.

Fifth, military discipline is principally a matter of leadership and culture. The most effective form of leadership is leadership by example, not leadership by court-martial. Most matters of military discipline are addressed through counseling, leadership, and command, not military justice. Further, where military justice is invoked, most dispositions are nonjudicial in nature. By quantifiable example, in 2013 the Army had 42,407 NJP, compared to 380 summary courts-martial, 373 special courts-martial, and 7I4 general courts-martial. ${ }^{\mathrm{I} 8}$ NJP includes punishment, but not sentencing or sentences. Military justice sentencing only arises in the context of courts-martial.

Sixth, commanders play a central role in the military justice process. Recent congressional debate and legislation has centered on the role of the commander in two areas: First, should the commander, with the advice of judge advocates, or should judge advocates alone make the decision to bring charges in the military justice system? Second, should commanders have the authority to grant clemency to a servicemember following court-martial conviction? This sentencing topic is reviewed below.

However, commanders-by which is meant those senior officers with authority to convene courts-martialalso play an indirect as well as a direct role throughout the military discipline continuum from NJP to court-martial sentencing. It is the commander who generally sets the command climate in which a unit operates. Is the unit led through inspiration and with respect, or through fear and with intimidation? Are military courtesies observed? Are all members of the command treated with dignity and respect, or are subtle or not so subtle forms of harassment and hazing tolerated?

The commander controls the command's investigative resources and budget along with the wherewithal to initiate or energize investigation. It is the commander, for example, and not the judge advocate, who will determine in a deployed context whether the mission is better served by deploying an MP or a criminal investigator for security or investigative purposes. And just as the commander can set the command climate in an infantry unit, he or she can do so in the manner in which law enforcement approaches their work. Does the commander trigger an investigation when an incident occurs? Does the commander demand answers, or wait for staff briefings? Are the necessary resources allocated to the investigative function? In garrison, such steps may be automatic, especially where an incident occurs outside the unit and is either reported or observed by military or civilian law enforcement authorities. But in the field, it is the commander who must decide how to balance his finite resources and allocate these resources among force protection, patrol, and criminal investigation.

Commanders also play a direct role, with the advice of staff judge advocates, as convening authorities in the courtmartial process. It is the commander who initiates an Article 32 investigation, the very rough equivalent of a civilian preliminary hearing. It is the commander who initiates and in most cases orders pretrial confinement. It is the commander who brings charges against an accused, or alternatively chooses not to charge or to proceed on the basis of administrative sanction or NJP. It is the commander who does or does not enter into a pretrial agreement. It is the commander who selects and designates court-martial members, if trial by members is elected. It is the commander who must approve the expenditure of money for defense or government experts and the travel of witnesses. It is the commander who must review and approve the court-martial. And it is the commander who may, in his or her discretion, grant clemency on findings or sentence to the accused.

Of course, this must all be done in a manner that is not directed to a particular court-martial outcome or in a manner that will viewed by members as constraining their discretion. Inappropriate command influence on the outcome 
of a military justice investigation or trial is known as unlawful command influence (UCI), which can lead to reversal with or without prejudice. ${ }^{19}$ At the same time, as indicated earlier, the military justice system is replete with and, in fact, could not operate without, lawful command influence.

Seventh, the military justice system is global in scope. It is intended to apply anywhere U.S. forces or naval vessels are deployed, including in combat or on the high seas. That means the sentencing process, like the court-martial itself, is supposed to function as effectively in the field under combat conditions as it does in garrison. As one can imagine, there are special challenges that arise in such context, such as gathering the members and witnesses, as well as the presentation of sentencing evidence through those witnesses.

Eighth, it is the sentence, and not the offense, that keys the door to appellate review. The question arises whether the threshold for appeal should be pegged to a sentence threshold of one-year confinement and/or a punitive discharge. Although it is generally the case that serious or complex offenses may generate more appellate issues, that is not necessarily the case. After all, appellate courts are charged with reviewing questions of law, which arise in the context of trial practice or pretrial investigation, whether or not a particular sentence is assessed.

Moreover, if appellate courts are in part intended to provide a uniform standard to the application of the Uniform Code of Military Justice, it might seem appropriate to review all cases and not just those at a sentence threshold. Moreover, in the case of the USCAAF, the Court plays the added function of providing civilian oversight to the courtmartial system. Surely, the principle of civilian control of the military applies regardless of sentence threshold.

Moreover, the Court's docket is sufficiently flexible to handle the additional cases that a lower sentence threshold would bring. Finally, where the sentence sets the threshold for obtaining appellate review, the government retains the ability through pretrial agreement to avoid appellate review, should it desire to do so.

Of course, there are arguments against the automatic appellate review of all special or general courts-martial as well. After all, Congress did not adopt such a model. First, there is the principle of finality, which allows both the Service and the servicemember to move on after court-martial in a case not resulting in a punitive discharge or lengthy confinement. Second, by extended analogy, the one-year threshold could be viewed as essentially equivalent to the distinction in civilian life between misdemeanors and felonies, and thus, an appropriate line of demarcation for an appeal of right. Furthermore, there is concern that if all cases were reviewed as a matter of right, appellate delay would ensue.

Ninth and finally, courts-martial are presided over by military judges. And, in the cases of trial before military judges alone, it is the judge that adjudges the sentence. Military judges are judge advocates selected by the senior lawyer in each service and designated to sit as trial or appellate judges. Generally, military judges will hold the rank of lieutenant colonel or colonel, although there are majors designated for this role as well as general officers. Military judges do not hold tenure; however, assignments are generally understood to last for three years, at which point a judge can return to line duty as a judge advocate. Once designated as a judge, trial assignments, or panel assignments on a CCA, are determined by the Chief Judge of the relevant circuit or court. Fitness reports, however, are generally written or reviewed by the senior lawyer in each service, known as The Judge Advocate General, and are based on officer qualifications rather than judicial criteria.

All of which means that for purposes of sentencing, military judges will generally not have the same years of experience as civilian life-tenured trial judges. Nor are the structural safeguards of impartiality and independence as strong as those provided by tenured office. On the other hand, military judges will have served all of their careers as military officers, and through a self-selecting process, are likely to have spent much if not most of their service time in the military justice field. Further, a military judge will more rapidly garner sentencing experience as well as perspective on appropriate and comparative sentences because they preside over courts of limited jurisdiction and thus repeatedly see and rule on the same offenses. Likewise, of those courts-martial occurring in combat theaters, five offenses comprised the majority of U.S. Army cases from 2003 through 2012 , by a wide margin: making a false official statement, offenses relating to alcohol, larceny of nonmilitary property, violation of general orders, and assault consummated by battery. ${ }^{20}$

\section{Military Sentencing Process}

Prior to sentencing, the government and the accused are entitled to put on sentencing cases. This can include the introduction of evidence in aggravation, extenuation, or mitigation. Victims of offenses under the UCMJ, as in the case of the Crime Victims' Rights Act, have "the right to be reasonably heard" before the court-martial prior to sentencing. In the case of the military, additional aggravating and mitigating factors beyond those familiar to civilian practice may include testimony regarding the crime's impact on unit cohesion, good order and discipline, and the military character (quality of service) of the defendant. The accused is also entitled, but not obliged, to make an unsworn statement before the court, which is subject to rebuttal but not to cross-examination.

The Manual for Courts-Martial recognizes five philosophies or purposes behind sentencing, as reflected in the standard Benchbook instruction:

I. Rehabilitation of the wrongdoer,

2. Punishment of the wrongdoer,

3. Protection of society from the wrongdoer,

4. Preservation of good order and discipline in the military, and 
5. Deterrence of the wrongdoer and those who know of his crimes and his sentence from committing the same or similar offenses. ${ }^{2 \mathrm{I}}$

Sentencing is also based on the premise that an accused should be sentenced based on the particular offense and the aggravating and mitigating circumstances surrounding that offense. There are no sentencing guidelines in the military justice system. However, there are maximum sentences and, for some offenses, mandatory minimum sentences to confinement. For example, the offense of premeditated murder includes a mandatory minimum of imprisonment for life.

In addition to confinement, military sentences can include fines, as well as military-specific punishments like confinement at hard labor, forfeiture of pay, reduction in grade, and punitive discharge (Bad-Conduct or Dishonorable Discharge) or, in the case of officers, dismissal from the service. Sentencing is also imposed in aggregate. That means the fact-finder is not required to designate a particular punishment or term of confinement for a particular offense, if multiple offenses are charged. As a result, where findings are reversed in part, appellate courts must apply a legal presumption that they can determine what sentence would have otherwise been imposed absent the overturned finding, or return the case for a sentence rehearing. In the case of a punitive discharge or dismissal, in accordance with service regulations and the Manual for Courts-Martial (R.C.M. III3), a punitive discharge is generally not executed until a servicemember's appeals are final, which accounts for the possibility that a servicemember will be returned to their status quo ante following appeal. ${ }^{22}$ However, as the posttrial process along with appeals can take a number of years, this has led on occasion to posttrial inmates receiving pay and benefits following conviction and while confined and awaiting discharge. As a result, the Code was amended in 1996 to provide that a military member sentenced to confinement for more than six months and/or sentenced to a punitive discharge shall not receive pay and benefits.

Once a sentence is adjudged at court-martial and the record of trial authenticated by the military judge, the record is sent to the convening authority for approval. It is at this stage of the court-martial process that the convening authority has an opportunity to offer clemency, a subject of present controversy as well as the subject of the next section.

\section{Sentencing Issues and Fault Lines}

Recent public and congressional attention on military justice has focused on the use of clemency in military sentencing. However, the third rail of the military justice sentencing debate revolves around the question of sentence consistency-between services and between offenders-and thus, whether the military justice system should include some form of sentencing guidelines. This section presents both issues. The goal is not to answer the questions and prescribe, but rather to inform the debate and in neutral manner set the stage for the articles that follow.

\section{A. Clemency}

Since the advent of the UCMJ, the Code has provided authority to convening authorities to grant clemency on findings and sentence as part of the convening authority's review and approval of courts-martial. Such authority has existed in some manner in U.S. military justice practice since the Articles of War of 1776 and George Washington at Valley Forge.

In the UCMJ, clemency authority is found in Article 6o, which until the National Defense Authorization Act of 2014 provided:

(a) The findings and sentence of a court-martial shall be reported promptly to the convening authority after the announcement of the sentence.

...

(2) Action on the sentence of a court-martial shall be taken by the convening authority or by another person authorized to act under this section. Subject to regulations of the Secretary concerned, such action may be taken only after consideration of any matters submitted by the accused under subsection (b) or after the time for submitting such matters expires, whichever is earlier. The convening authority or other person taking such action, in his sole discretion, may approve, disapprove, commute, or suspend the sentence in whole or in part.

(3) Action on the findings of a court-martial by the convening authority or other person acting on the sentence is not required. However, such person, in his sole discretion, may-

(A) dismiss any charge or specification by setting aside a finding of guilty thereto; or

(B) change a finding of guilty to a charge or specification to a finding of guilty to an offense that is a lesser included offense of the offense stated in the charge or specification.

Pursuant to Article 6o, the now convicted accused has the right to petition the convening authority for clemency before the convening authority takes action to approve the findings and sentencing. Usually, the petition is filed before the same convening authority that brought the charges in the first place.

Whereas heretofore, Article 60 permitted a convening authority to dismiss the findings with prejudice or disapprove the sentence in its entirety and award "no punishment," in practice clemency is most often exercised in sentence mitigation, if it is exercised at all; however, here as elsewhere the absence of statistics makes empirical observations difficult. In some circumstances, a convening authority might reduce a sentence in response to government misconduct or error in the course of trial (for example, undue appellate delay). In rarer circumstances, a convening authority might reduce a period of confinement or mitigate a reduction in rank in recognition of 
exemplary combat service. Rarest of all is the exercise of clemency resulting in the dismissal of a finding of guilt, as a matter of grace, as opposed to the legal recommendation of a staff judge advocate. ${ }^{23}$ However, in part because the military justice system is decentralized and designed to be exercised at the convening authority and command level, centralized statistics have not been kept on the exercise of clemency. Thus, empirical data on the actual exercise of clemency is sparse, and anecdotal or reductive evidence tends to drive debate. Thus, the military justice system would be well served by a system that better tracks trial inputs and outcomes, provided it is a subtle enough system to identify the sorts of distinctions between cases involving the same offenses, but that result in different sentencing and clemency outcomes.

What is the debate?

The theory behind clemency authority is twofold. First, it provides for military necessity and exigency by giving the commander authority to eliminate or reduce a finding or sentence in order to return a soldier to duty and, if necessary, the battlefield. This is not purely theoretical, or the stuff of movies like The Dirty Dozen, in which a group of rogue and violent criminals is promised clemency in return for undertaking a "suicide" mission behind German lines. Recall that the Code was drafted in the wake of World War II and during the course of the Korean Conflict. There were approximately I.7 million courts-martial during World War II. ${ }^{24}$ That is a lot of courts-martial, potentially resulting in a lot of soldiers being taken off the line to serve sentences. Now consider that the Germans have broken through in the Ardennes Forest during the Battle of the Bulge, or that the North Koreans are streaming south to trap the Americans in the Pusan perimeter. In such contexts, the use of clemency authority for both findings and sentences makes some sense. A commander might well clear the stockade or brig to defend the line.

Recall as well that the military justice system is intended to serve as a disciplinary tool to uphold good order and discipline and not only to adjudicate criminal responsibility and mete out punishment. For that reason a commander might use some measure of clemency as a tool to recognize past meritorious service and thus set an example for other soldiers. Wielded wisely, the use of clemency as grace can inspire performance and enhance morale and discipline. Of course, if wielded unwisely, it can dramatically have the opposite effect. There is surely a moral and optical difference between granting clemency to a good soldier who got in a bar fight and a rapist.

The second theory behind clemency authority is rooted in democratic principle, including recognition that the state, in the form of prosecutorial authority may, indeed, will overreach. As James Madison stated in the Federalist Papers, "If men were angels, no government would be necessary. If angels were to govern men, neither external nor internal controls on government would be necessary. In framing a government which is to be administered by men over men, the great difficulty lies in this: you must first enable the government to control the governed; and in the next place oblige it to control itself." Therefore, the clemency authority, like the President's pardon power or a state governor's commutation power, recognizes the state's potential to overreach, perhaps especially where national security is concerned. Therefore, the executive-the President, the Governor, or in military context the commander-is granted authority to mitigate sentences as well as findings. Because the commander is closer to the circumstances surrounding an offense as well as the factors that might mitigate in favor of clemency, the argument is that the commander should retain the authority rather than a more senior and central authority, or indeed the Commander in Chief.

In the drafting of the Code, the risk of overreach was an acknowledged and in some cases a specific concern. Indeed, many provisions in the Code were adopted to guard against the potential of government overreaching and to provide for military discipline without sacrificing servicemembers' rights. Of course, there is always room for debate, then and now, on just where the line falls and should fall. But there is no question the Code includes provisions to protect servicemembers' rights for this very purpose. Article 3I rights warnings, for example, which are roughly similar to but more robust than Miranda Warnings, were included in the Code sixteen years before Miranda out of concern that military grade and power differentials could potentially coerce servicemembers into acts of involuntary self-incrimination. Likewise, the Code prohibits what is known as unlawful command influence, an effort by a command or a commander to influence the outcome of a court-martial outside the bounds of appropriate command influence as authorized and recognized in the Code.

As a final example, the Code provides servicemembers of any grade and regardless of means, military defense counsel free of charge through appeal to the Supreme Court. As a result, at courts-martial the government and the accused are usually represented by counsel of equivalent grade, caliber, and training, acting with the zeal and diligence of a professional military officer. Thus, clemency authority should not be viewed in the abstract, or solely through the lens of the role of the commander, but also as one of a number of provisions in the Code that were intended to safeguard servicemembers' rights while also advancing good order and discipline and the military mission.

However, there are arguments against clemency generally, or clemency in certain cases, as well. First, because Article 60 grants clemency authority to convening authorities generally, by definition it will be exercised by many commanders representing diverse backgrounds, different services, and varied grades. This can and does result in inconsistent applications, notwithstanding seemingly similar circumstances. Given the prescripts against unlawful command influence, a more centralized policy on the exercise of clemency could be problematic and is generally eschewed.

Second, to the extent clemency was intended as a safeguard against prosecutorial overreaching, the Code in 
practice provides multiple safeguards to protect the rights of servicemembers and has placed those safeguards in the hands of military judges and ultimately federal appellate court judges at the USCAAF. In addition, the service Courts of Criminal Appeal have sentence appropriateness authority and can review the factual underpinnings of convictions appealed as a matter of right. Moreover, the civilian judges of the Court of Appeals for the Armed Forces function entirely outside the military hierarchy. The case law of these courts includes such doctrines as multiplicity, multiplication of charges (addressed to duplicative charging as well as overcharging), as well as the principle that sentences should not be highly disparate in closely related cases. ${ }^{25}$

Third, clemency authority is unbridled. It is, or was, an available authority in the case of murder and rape, and not only military "misdemeanors." Thus, as a matter of theory, it is available in circumstances and in cases where the government has not overreached and where the commander could not possibly want or desire to return a military member to duty, including in cases where the member has received an adjudged punitive discharge. The Dirty Dozen aside, is it realistic or appropriate to suppose that a commander will release violent offenders in the case of military necessity? This leads to a fourth and related concern.

The clemency authority has been used in unintended ways, that is, outside the theories presented above, including by commanders substituting their judgment for that of court-martial fact finders regarding the credibility of the evidence on questions of guilt or innocence. Clemency was not intended as a substitute for trial and the careful evaluation of evidence at trial by the fact finder, including the demeanor of witnesses. Rather, it was intended as a tool to mitigate overreaching or provide for executive grace. This concern has been highlighted and amplified by a handful of cases providing anecdotal indication that clemency has been used to second-guess verdicts in cases involving serious offenses.

In response to these and other arguments, the Congress amended the Code in 20I4 to limit the availability of clemency as to both findings and sentence based on the nature of the offense and sentence adjudged. Specifically:

(c) (3) (B) If the convening authority or another person authorized to act under this section acts on the findings of a court-martial, the convening authority or other person-

(i) may not dismiss any charge or specification, other than a charge or specification for a qualifying offense, by setting aside a finding of guilty thereto; or

(ii) may not change a finding of guilty to a charge or specification, other than a charge or specification for a qualifying offense, to a finding of guilty to an offense that is a lesser included offense of the offense stated in the charge or specification.
(C) If the convening authority or another person authorized to act under this section acts on the findings to dismiss or change any charge or specification for an offense (other than a qualifying offense), the convening authority or other person shall provide, at that same time, a written explanation of the reasons for such action. The written explanation shall be made a part of the record of the trial and action thereon.

(D) (i) In this subsection, the term 'qualifying offense' means, except in the case of an offense excluded pursuant to clause (ii), an offense under this chapter for which-

(I) the maximum sentence of confinement that may be adjudged does not exceed two years; and

(II) the sentence adjudged does not include dismissal, a dishonorable or badconduct discharge, or confinement for more than six months.

(ii) Such term does not include any of the following:

(I) An offense under subsection (a) or (b) of section 920 of this title (article I20). [Rape and sexual assault.]

(II) An offense under section 920b or 925 of this title (articles I2Ob and I25). [Sexual assault and sodomy.]

(III) Such other offenses as the Secretary of Defense may specify by regulation.

The question remains, with respect to those offenses not covered by the terms of the NDAA of 20I4, whether the arguments and purposes for clemency that resulted in its adoption in I950, or for that matter, previous Articles of War, are as relevant and apt in today's legal context.

\section{B. Guidelines and Consistency}

There are no sentencing guidelines in the military justice system. There are a few mandatory minimums. All of the offenses in the Code carry maximum sentences. As noted, military sentencing is predicated on the principle of individualized sentencing. That means that servicemembers convicted of offenses are sentenced based on the nature of the specific offense(s), including any mitigating and aggravating factors associated with that offense or that offender.

As echoed in debates over sentencing guidelines in Article III Courts and Booker, ${ }^{26}$ there are similar arguments for and against the application of guidelines in the military justice system. To start, individualized sentencing (without guidelines) recognizes not only that offenses can present a wide range of disparities in gravity and culpability, as well as a wide breadth of extenuating and mitigating factors. Those disparities, the argument goes, can have sufficient breadth as to make all but the broadest guideline bands inapt or unfair in context.

Some of these factors are military specific, some not. For example, in any given case, the offender may express 
a different degree of contrition, or offer a different degree of rehabilitation potential, or a different level of cooperation to law enforcement authorities, if any. So, too, a decision to plead guilty, and thus spare victims the necessity of testifying or the government the expense of trial, may warrant appropriate sentence adjustment outside fixed sentence parameters. The fact finder may also assess on an individual basis different degrees of culpability for the same offenses. For example, a special defense might apply or mitigate in one case, but not another.

Military-specific factors may also come to bear and justify variation in sentence, such as the impact of an offense on unit morale and capability, whether the offense took place during combat operations and was shaped by those operations, or perhaps the role of PTSD on the offender. It follows that the five sentencing philosophies described earlier will not apply in the same manner in every case involving the same offense; their application may vary widely so as to escape a fair and just application of all but the widest guideline bands.

Embedded in the debate over guidelines, that is, mandatory minimums, is an institutional argument about whether judges or politician-policymakers are best suited to determine what is a fair and just sentence in a given case, and whether that judgment should be based on abstract guidelines or case-contextual factors. In Article III context, this is a debate over whether the Congress or the judiciary is better suited to determine fair and just sentences.

As there are arguments against Guidelines in military and other contexts, there are also arguments for Guidelines in military context. First, and perhaps foremost, is the argument that in what is supposed to be a uniform system of military justice, like sentences should be meted out for like offenses regardless of service component or grade. Because military appeals courts and the USCAAF can lower a sentence, but not increase it, uniformity will only come through consistent trial practice or with the application of mandatory minimums and/or guidelines.

Second, and related to this first argument, is the concern regarding the disparate treatment between officers, especially senior officers, and enlisted personnel. This is colloquially referred to as "different spanks for different ranks." Whether this received wisdom is based on erroneous and anecdotal perceptions, or is well-founded and supportable by empirical data, is beyond the scope and capacity of this article. However, surely one can conclude that a system of justice that is perceived to treat offenders differently based on grade alone will be viewed as a less credible system than one that treats like offenders in like manner, and is perceived to do so. Moreover, such perceptions of disparity can affect military morale and undermine confidence in military leadership.

The debate about guidelines is well known, indeed better known to a civilian than a military audience. This article does not presume to meaningfully add to that debate; rather the goal is to identify military sentencing factors that might add to the guideline debate. Here are the takeaways.
As previously noted, the military justice system is decentralized. This means that statistics, to the extent they exist, are diffuse and available at the local command or service level, if at all. Moreover, sentencing statistics do not exist in context, which means although it may be possible to graph numerical outcomes, such statistics mean very little without the accompanying context of victim impact, crime detail, and mitigating factors, if any.

There is a legal adage that "bad facts make bad law." Policymakers should take special care when addressing sentencing in the military context to avoid making decisions based on anecdotal evidence, such as the case where the rapist or child pornographer received no confinement or the first-time drug user received thirty years. This is a subject for which empirical data can especially bring truth to power. But the data must be accurate and complete. Better statistics are needed.

Consideration of military sentencing must also account for the dual purposes of military justice, which is to say, military discipline and justice and the relationship between the two. There are military considerations that should factor into military sentencing that do not factor into civilian sentencing as both matters of extenuation and mitigation. For example, although sexual assault is endemic in society at large, including on college campuses, in the military context it presents issues not only of victim impact and justice, but also of good order and discipline. Where sexual assault occurs between servicemembers and/or involves disparities in grade and power, it also directly impedes morale and welfare, unit cohesion, and mission accomplishment. Consider as well the potential range of appropriate sentencing outcomes from no punishment to confinement that might occur with reference to adultery, which is not a criminal offense in most civilian contexts and rarely prosecuted regardless. In one case, a squad leader soldier is legally separated from his spouse and engages in sexual relations with a civilian girlfriend, and the suspected offense of adultery is reported by a member of the unit who is resentful for having been assigned weekend duty. In another case, the squad leader is deployed to Afghanistan where his leadership proves essential as a combat patrol leader-that is, until rumors start circulating in the unit that an officer who has not deployed with the unit is "dating" the squad leader's wife. The rumor is soon confirmed, causing morale in the unit to plummet and unspoken tension between the unit's NCOs and officers. Whether sentencing guidelines might successfully capture the appropriate range of just options here is the legal policy question. ${ }^{27}$ Whether such issues are better addressed through guidelines, presidential directives, or case-specific judicial application is the process question.

Moreover, the institutional context is different in the military justice system. As noted above, whereas military judges do not serve with tenure, they are exposed to a repetitive practice, especially around certain military and common law offenses, offering perspective on a normative 
range of sentences. It follows that the longer the tenure, the deeper the perspective and knowledge.

\section{Military Sentencing Nutshells}

The two previous sections addressed clemency and sentencing guidelines, or rather the absence of guidelines in the military context. In this section, the article introduces five additional sentencing matters that warrant analysis and review. Perhaps because it would be injudicious to do more than introduce the topic here, they are presented in nutshell form. This is not a reflection on their relative importance, but because the arguments are clearly developed elsewhere, including in case law.

\section{A. Is the sentencing process fast enough?}

Speed, or perhaps in a less pejorative sense, the timely administration of justice, has long been viewed as a strength of the military justice system. Among other things, the timely administration of justice more effectively serves the sentencing philosophy of deterrence. In the military context, this means the dual objectives of justice and good order and discipline. As the saying goes, "justice should be seen to be done, as well as done." This is one reason emphasis is placed on the system's capacity to administer justice in deployed environments as well as in garrison, at sea as well as on land.

Imagine, for example, the effect on unit morale if the suspected barracks thief remains in the unit because it takes the convening authority three hundred days to approve findings and sentence. Likewise, imagine the effect on the victim of sexual assault who remains in the same unit with the perpetrator, or where the perpetrator has been removed to a new unit, but the victim continues to see the perpetrator on base. Speed matters. It matters even more in military context, because the perpetrator of an offense and/ or the victim are generally known to the unit, and however large the unit, everyone knows or at least has a perception about when and whether "justice has been done."

Aside from the general principle of deterrence, the question arises, is the sentencing process as fast as it can be, or should be, consistent with due process, and if not, where can it improve? Case law and recent Army studies suggest two areas of concern. First, case law suggests problems with appellate delay. As Barker v. Wingo makes clear, where delay is of sufficient duration and impact it raises due process concerns. ${ }^{28}$ What military case law makes clear is that there have been problems with appellate delay in the military, and some of the problems stem from sentencing process. In particular, the role of the convening authority in approving findings and sentence as well as in reviewing for clemency often adds weeks, months, and sometimes even years to the court-martial process. ${ }^{29}$ The question arises, are there ways of streamlining the posttrial process so that there are not so many steps. Alternatively, should the Code or the Rules address slow staff work of the sort that, were it to occur in an operational setting, would immediately lead to the relief (firing) of the officer involved.
In addition to raising due process concerns and undermining the deterrent effect of courts-martial, appellate delay combined with personnel law may impact the exercise of prosecutorial discretion by convening authorities by encouraging commanders not to pursue criminal charges. In the military, findings and sentences are not final until appellate review is complete. Thus, even if a servicemember is sentenced to confinement and a punitive discharge, the punitive discharge generally is not executed until the appeal is final.

As a matter of personnel law, this has the effect of encumbering a full-time-equivalent (FTE) position in the military. Because there is a statutory cap on the number of personnel each service may carry at any one time, there is incentive to administratively discharge and immediately separate a servicemember from the Armed Forces rather than court-martial the servicemember if a commander believes that it will take too long for the court-martial process to play out. On a service scale the incentive may appear minimal. With an authorized army active duty end-strength of 550,064 , and 465 and 725 special or general-courtsmartial per year, respectively, it is hard to imagine as a matter of Army policy that the service would adopt an Admin Discharge policy for FTE reasons alone, nor has it.

However, on a tactical level, at the regimental or Brigade level, the incentives might change, where a single soldier or tens of soldiers may make a difference, especially for a deploying unit. Indeed, there is some reason to believe this concern has played out. This is indicated in the Army Gold Book, compiled under the auspices of the Army Vice Chief of Staff in 2012.

This analysis, which reflects a significant sample size and uses population adjusted rates, demonstrates markedly consistent trends that indicate a potentially troubling gap in disciplinary accountability. Even more puzzling is the fact that separations for misconduct have increased by $57 \%$ (from 5,606 to 8,8I5) in the same period. Simply put, disciplinary accountability has reversed its position with administrative separations from high disciplinary actions and low administrative separations to low disciplinary actions and high administrative separations..$^{30}$

This same incentive might arise in the context of budget cuts and corresponding personnel cuts.

The questions presented to policymakers are: Is this concern supported by empirical data? If so, should personnel or sentencing law be amended so that charging decisions are made based on the four corners of the evidence presented and not distorted by questions of military readiness and FTEs? More broadly, policymakers should ask: Consistent with due process, are there ways to streamline the process from adjudication to finality? Would it help to require sentencing by judges alone? What if judges were given tenure and thus became even more proficient and practiced in the sentencing process? Does the array of punishments available for sentencing unduly delay or confuse the process? For example, is it necessary to 
distinguish between a bad-conduct discharge and a dishonorable discharge?

\section{B. How should the collateral consequences of military justice be addressed in sentencing, if at all?}

Military justice sentencing raises a number of issues regarding the handling of the collateral consequences of court-martial conviction and sentencing not found in civilian practice. Collateral consequence means an administrative action that is a direct result of a court-martial conviction or sentence, but that is not itself a punishment adjudged at court-martial. For example, a punitive discharge adjudged at court-martial can lead to the loss of retirement pay, Veterans Administration health benefits, and GI Bill educational benefits.

In some cases the collateral consequences are the same in military and civilian context. Within the military system, however, the subject of ongoing appellate debate continues regarding how those consequences should be addressed, if at all, at sentencing. The primary examples are sex-offender registration and deportation in the case of a noncitizen convicted of a felony. ${ }^{3 \mathrm{I}}$

In many cases, an objective observer might well view the collateral consequence as more severe and permanent than the sentence adjudged at court-martial. For example, a retirement-eligible servicemember who is convicted of a one-time use of marijuana could face up to five years' confinement and a bad-conduct discharge. But if the servicemember is adjudged a punitive discharge, he or she will also lose retirement benefits. For a 38-year-old E-5 with twenty years of service, that would amount to $\$ 37,138$ per year in base pay.

The legal policy question that arises with respect to good order and discipline is whether the all-or-nothing loss of retirement benefits creates incentive, or more precisely disincentive, for dependents to report offenses in or against the family. From an anecdotal perspective alone, the USCAAF has seen numerous cases where families have not reported or delayed reporting sexual assaults against family members out of fear that a court-martial conviction will result in the loss of housing and retirement pay and benefits. There are cases as well involving alleged recantation, where the facts alleged suggest one parent or another has realized the impact of a child's testimony and pressured the victim-witness to change his or her testimony.

There are two recurring issues that arise on appeal in military sentencing practice with respect to collateral consequences. First, should a servicemember be permitted to address the collateral consequences of conviction as part of his sentencing argument in order to mitigate a potential court-martial sentence? At court-martial a convicted servicemember is permitted to make an unsworn statement before the fact finder as a matter of right. Such statements are generally limited to those relevant to sentencing, including matters in extenuation, mitigation, and rebuttal. At the same time, the rules of evidence are relaxed on sentencing and a servicemember is allowed broad leeway in what he presents. In addition, the military judge typically issues a standard Benchbook instruction to Members (a military judge, like an Article III judge, is presumed to know the law and apply it), stating that an unsworn statement is not evidence and that it is within the sole discretion of Members as to how much weight, if any, to give the statement.

In the case of Talkington, for example, the servicemember sought to bring to the Members' attention that he would have to register as a sex offender for the remainder of his life. ${ }^{32}$ The government objected, noting that sex offender registration is a collateral consequence of conviction and not for members to determine as part of their sentencing. The military judge split the difference and both instructed the members that it was within their sole discretion to determine what weight if any to give the defendant's statement, but at the same time the statement was fraught with problems and that sex offender registration was "not a matter before them."

On appeal to the USCAAF the court divided 3-2 on whether the military judged erred in his instruction. The three-judge majority of the court concluded the judge had acted within his discretion because sex offender registration was a collateral matter, which should not be placed before members. The two-judge dissent argued that collateral or not, sex offender registration was integral to the criminal proceeding, would be required by Defense Department Directive in all fifty states, and thus was an inexorable and direct result of court-martial conviction. Thus, rather than have members apply their own received wisdom and perceptions regarding sex offender registration without instruction from the judge, the judge should provide appropriate instruction as tailored in the dissent.

The second recurring issue revolves around the duty of competent counsel to advise their clients regarding collateral sentencing matters. Is it ineffective assistance of counsel to fail to affirmatively advise a client regarding the collateral consequences of court-martial conviction,

including when such collateral consequences are a certain result of conviction?

Three lines of appellate argument are evident. First, as a general matter counsel is not required to advise on all collateral matters, but if they do, the advice rendered must be accurate. Second, in addressing collateral matters, courts will distinguish between the impact of collateral matters on knowing pleas and the impact of such matters on courtmartial sentencing. ${ }^{33}$ Third, in light of Padilla and other case law, the distinction between collateral and noncollateral matters on sentencing is not as clear as it once was, and the law continues to evolve. Whereas some courts and some circumstances treat collateral matters as integral to the criminal proceeding where they are a certain result of the criminal proceeding, other courts and circumstances do not. Thus, the surest safeguard against confusion or error on this point is accurate advice and tailored instructions.

In addition, after over a decade of conflict and in many cases multiple tours of combat duty, policymakers should consider how veterans benefits, especially health benefits, 
should be treated during the sentencing phase of trial. For example, as a matter of substance, should a court-martial conviction lead to the termination of some or all of a servicemember's benefits, including health benefits? Are, for example, the interests of justice and society better served by terminating health benefits in the event of conviction or by continuing those benefits in a confinement and postconfinement setting where those benefits address battlefield scars of a physical or mental variety occurring before a soldier's misconduct? Here the sentencing principle of rehabilitation and correlated risk of recidivism may come into conflict with principle of retributive sentencing and victim impact. Should policy distinguish between health and other benefits?

Depending on the answer to these questions, the sentencing process question becomes, should the parties be able to argue in sentencing mitigation or aggravation the loss of veterans' benefits? In legal terms, should the loss of health care benefits directed toward service injuries or consequences be viewed as collateral or a direct consequence of court-martial conviction and thus thrown into the sentencing deliberative mix?

Of course, the most important collateral consequence of conviction may be the "what" and "where" of confinement.

\section{Military Confinement}

As a general matter, servicemembers sentenced to confinement pursuant to the military justice system will serve their sentences in military correctional facilities (MCF). Sentences to confinement under one year in length will usually be served in a local confinement facility, e.g., a base brig, stockade, or prison. In the case of sentences to confinement of up to five years in length, servicemembers will generally serve their sentences at a level II or mediumsecurity facility, such as those located in Sembach Kaserne, Germany, ${ }^{34}$ Charleston, South Carolina, Fort Leavenworth, Kansas, Joint Base Lewis-McCord, Washington, and Miramar, California. In the case of sentences of ten years or longer, confinement will be served at the military's single maximum-security facility at Fort Leavenworth, Kansas, which is located adjacent to, but is distinct from, the medium-security prison at Fort Leavenworth. This is also the site of military death row. Female prisoners with lengthy sentences, however, generally serve their time at the Naval Consolidated Brig, Miramar, in San Diego. ${ }^{35}$

A number of aspects of military confinement are distinct from civilian confinement, as suggested in the following mission statement from the Defense Department Directive governing confinement:

The MCF shall be operated to maintain good order, discipline, safety, and security. Procedures for operating facilities, processing prisoners, and conducting programs shall be uniform to the maximum extent possible. ${ }^{36}$

To start, the regulations and the culture contemplate that at least some confined service personnel will be, or could be, returned to active duty, and if not active duty, certainly to civilian life. Thus, both good order and rehabilitation are integral to military confinement. In addition, military prisoners remain subject to the UCMJ under Article 2 while serving their sentences, even where a sentence includes punitive discharge from the Armed Forces or where a servicemember has reached the end of his enlistment. Further, military confinees are invariably firsttime offenders. Otherwise, they likely would not have been permitted to enlist in the armed forces. Military service also means they are likely to have a high school education and that they are persons who at one time took an oath to support and defend the Constitution.

However, assignment to a military confinement facility is not a foregone conclusion. DOD Regulations permit the service of confinement in civilian facilities in two circumstances: First, "[i]f an MCF, including military/security police detention cells, is not reasonably available, prisoners may be confined in civilian facilities used by the U.S. Marshals Service. If a facility used or approved by the U.S. Marshals is not reasonably available, a military prisoner may be transferred to a facility accredited by the American Correctional Association (ACA) or facility accredited by the state in which the prisoner is to be confined." 37 Further, "a prisoner may be transferred to FBOP facilities with the concurrence of or by direction of the appropriate Secretary of the Military Department concerned... and by agreement with the FBOP." ${ }^{8}$ The potential for transfer can be used as a source of leverage to maintain good order and discipline within military confinement facilities. That is because the received wisdom is that military confinement facilities are run with military order that keeps the system more safe and clean than Bureau of Prisons (BOP) prisons. ${ }^{39}$ Most importantly, military prisons do not face the serious risks involved with prison overcrowding that have become a major issue in some BOP and state prisons in the United States. ${ }^{40}$

In recent years, the Base Realignment Commission process has resulted in the consolidation of military correctional facilities. It is outside the purview of this article to predict or project whether additional consolidation is likely or whether additional budget constraints will result in more frequent recourse to these regulatory permits, allowing the transfer of military prisoners to civilian facilities. However, attention to such trends is prudent from those who study sentencing process and impact.

In general, administrative issues relating to military confinement are considered collateral matters, and thus beyond the jurisdiction of military courts and USCAAF review, either on direct appeal or through habeas petition. For example, the case law is clear that although "each accused deserves individualized consideration on punishment," collateral matters including the possibility of parole or good-time credit "should not be considered by the members or military judge" in sentencing. ${ }^{4 \mathrm{I}}$ However, appeals do arise regarding the imposition of pretrial or posttrial confinement where the claim is arguably a direct product of the court-martial sentence or is otherwise 
governed by a provision of the Code. The jurisdictional fault line tends to fall between whether confinement conditions are integral to the sentence of confinement adjudged at court-martial and therefore a direct result of court-martial subject to review, and whether confinement questions are purely postconviction matters and thus entirely collateral to the jurisdiction of military justice courts.

Appeals addressing the conditions of confinement generally arise in four related areas. First, Article 13 of the UCMJ prohibits pretrial punishment.

No person, while being held for trial, may be subjected to punishment or penalty other than arrest or confinement upon charges pending against him, nor shall the arrest or confinement imposed upon him be any more rigorous than the circumstances required to insure his presence....

Thus, Article I3 prohibits intentional efforts to punish a soldier while he is pending trial, for example, through mockery or through duties beyond those ordinarily assigned to someone of like grade and under like circumstances. The intent to punish is often decisive in considering such claims. In addition, the Article is addressed to the excessive imposition of constraint beyond that which is necessary under the circumstances. Except in situations where the government's intent and behavior might amount to unlawful command influence, the ordinary recourse after the fact is to seek credit for such conditions.

Rule for Court Martial 304 expands on Article 13 by further prohibiting the imposition of pretrial punishment, and providing that "prisoners being held for trial shall not be required to undergo punitive duty hours or training, perform punitive labor, or wear special uniforms prescribed only for post-trial prisoners." This Rule, which is generally understood to prohibit the "comingling" of preand posttrial prisoners, is based on the presumption of innocence and provides further granularity to Article I3.

Second, although a prisoner has no right to determine his or her place of confinement, the location of confinement may nonetheless arise on appeal in the context of a plea case. This might occur, for example, where an accused has entered into a plea agreement on the understanding that he or she will be confined under certain conditions, for example, receive certain counseling or medical care, or in a certain location. The appellate question in such circumstance might address whether such a plea was knowingly and voluntarily made when the condition is not honored, or cannot be honored after the fact. Among other things, cases indicate courts might look to whether a condition is material to the plea, whether the negotiated conditions are consistent with public policy, and whether the government's ability or inability to honor such conditions was known or should have been known at the time. If called for, the remedy in such instances will likely be addressed to the providence of the plea.
Third, Article I2 states that "no member of the armed forces may be placed in confinement in immediate association with enemy prisoners or other foreign nationals not members of the armed forces." There are not many cases involving the application of Article I2. ${ }^{42}$ However, in $20 \mathrm{I} 4$ the USCAAF held that this provision did not apply only to detention with enemy prisoners and "other foreign nationals," but to foreign nationals generally, including those within the U.S. Bureau of Prisons system as well as state and local confinement facilities. ${ }^{43}$ As there are currently over 350,000 foreign nationals confined within the U.S. prison system, it is not yet clear what impact, if any, this decision will have on the capacity to confine military prisoners in civilian facilities, what the sanction will be for doing so, or whether the President or the Congress will seek to change the law in this area.

Finally, appeals may be taken either on direct review or through habeas petition asserting that the conditions of confinement violate a prisoner's 8th Amendment right against cruel and unusual punishment.

\section{Should age (ever) serve as a mitigating sentencing factor?}

One topic that has not heretofore arisen in military case law is whether age should factor into sentencing based on new understandings about the development of the frontal lobe of the brain and the impact of such development on the capacity of individuals to exercise ethical and moral judgment. The law has long recognized a distinction in culpability between adults and children. What has changed in the past ten years is our understanding, or at least the understanding of neuroscience, about the age at which the cognitive development of the brain's capacity to exercise ethical judgment occurs. Research has specifically found that not only does the frontal lobe undergo more change during adolescence than any other time of life, but it is also the last part of the brain that develops. This means "that even as [adolescents] become fully capable in other areas, [they] cannot reason as well as adults." 44

There is a certain irony here as much of the studies of the military wounded from the Iraq and Afghanistan conflicts focus on the injury to the frontal lobe and its link to post traumatic stress disorder. ${ }^{45}$ It might also be noted that as a matter of international law, but not U.S. law, persons under the age of $\mathrm{I} 8$ are viewed as "child soldiers." However, U.S. law permits persons who are I7 years of age to join the U.S. Armed Forces with informed parental consent.

As brain science has developed over the course of the past ten years, so has the legal precedent for juvenile sentencing. In Roper v. Simmons, the Supreme Court found that imposition of the death penalty on juveniles is unconstitutional. ${ }^{46}$ Additionally, life without parole cannot be given to juvenile offenders who committed nonhomicide offenses. ${ }^{47}$ In Roper, the Court noted that society now views juveniles "as less culpable than the average criminal." 48 The Court in Graham reaffirmed the Roper reasoning by discussing the fact that juveniles are simply less culpable, 
and thus, the rationales for both retribution and deterrence, both bases for punishment, are diminished. ${ }^{49}$

Most recently, the Supreme Court found that mandatory schemes for sentencing juveniles are unconstitutional. Preventing sentencers from considering the age of the defendant and evaluating the proportionality of the punishment “contravenes Graham's and Roper's foundational principle: that imposition of a State's most severe penalties on juvenile offenders cannot proceed as though they were not children." 50 In that decision, the Supreme Court cited the progress of brain science, which shows there are "fundamental differences between juvenile and adult minds." ${ }^{\mathrm{I}}$ How, if at all, such science and these court decisions should apply in military context has not been definitively addressed in a military appellate setting.

\section{E. Death Penalty}

The Code currently provides a maximum sentence of death for fifteen offenses, including certain offenses where the penalty of death is possible during wartime, but not during peace. The death penalty is also a listed penalty for certain offenses for which the underlying offense does not include the taking of a life, including rape. Indeed, the last person executed in the military justice system was convicted of rape and was executed in I96 $\mathrm{I}$ at the U.S. Disciplinary Barracks, Fort Leavenworth, Kansas. As of January 2015, there are six people on military death row at Fort Leavenworth. Each of these inmates was convicted of one or more murders.

Clearly, any review of sentencing in the military should include within its gambit consideration of the death penalty. A number of policy issues are evident, including:

- Should there be a death penalty in the military justice system?

- If so, is the military justice system staffed and equipped to provide an appropriate level of representation?

- If adjudged, should a death sentence in fact be executed?

- Does a military death penalty serve its intended policy purposes?

There are also a number of legal questions that will, in context, need to be addressed by the military justice system relating to due process and the Code's consistency with current Supreme Court precedent. However, these questions are more appropriately and judiciously addressed elsewhere, including in the articles that follow. The purpose of this brief section is therefore to expressly recognize the death penalty as belonging on the list of military sentencing matters warranting review and discussion, without searching for or crossing the line as to what is or is not judicious commentary.

\section{Conclusion}

This article introduced the reader to the nature and process of court-martial sentencing. It also identified some of the legal policy issues associated with that process, which issues prompt the questions: Is military justice, including sentencing, on the march? If so, to where is it marching?

The answer depends on a number of questions addressed in these issues of the Federal Sentencing Reporter.

I. What are the purposes of military justice sentencing?

2. Does current law effectively promote and support those purposes? Does the substance and process of military sentencing promote justice as well as good order and discipline?

3. Is military justice sentencing fast enough? If not, why not? Can changes be made to speed the process, consistent with due process?

4. Is military justice sentencing uniform, predictable, just, and fair?

Specific questions should follow from these threshold framework questions, including:

I. Should military judges have tenure?

2. Should the UCMJ adopt sentencing guidelines?

3. Should members or judges alone adjudicate sentences?

4. What role should victims play in the sentencing process, and are there sound legal or policy reasons why that role should differ from civilian practice?

5. Should commanders continue to exercise Article 60 clemency, and if so, at what level of command and in regard to what type of offenses?

Regardless of the answer to these questions, it is clear that a better informed policy outcome will occur with more reliable data. Therefore, regardless of one's answers to these questions, the Congress and the President should consider the manner in which statistics are kept and on what subjects. Such data will permit policymakers to legislate on the basis of empirical evidence as opposed to anecdotal or emotional response.

It will also better occur with the benefit of external comment and oversight that comes from having an active and interested academic bar address today's topics. In this regard the Federal Sentencing Reporter and the articles that follow are making an important contribution to public policy and military justice.

\section{Notes}

The author wishes to thank John Sparks, Sarah Mortazavi, Ingrid Price, and Clair Viglione for their helpful comments and edits; however, the views expressed herein are those of the author alone. Likewise, any mistakes herein are those of the author alone as well.

1 These two functions are intertwined. See Report to William C. Westmoreland, Chief of Staff, U.S. Army, by the Committee for Evaluation of the Administration of Military Justice (a military court-martial "is an instrument of justice and in fulfilling this function it will promote discipline."), available at http://www. loc.gov/rr/frd/Military_Law/pdf/report-Westmoreland_ more.pdf. 
2 Art. 66, UCMJ, 10 U.S.C. $§ 866($ a). As a matter of law, civilians might also be appointed to sit on a CCA. But see Edmond v. United States, 520 U.S. 651 (1997); Ryder v. United States, 515 U.S. 177 (1995); Weiss v. United States, 510 U.S. 163 (1994); United States v. Janssen, 73 M.J. 221 (C.A.A.F. 2014); United States v. Carpenter, 37 M.J. 291, 294 (C.M.A. 1993) cert. granted, judgment vacated, 515 U.S. 1138 (1995).

$3 \quad$ Art. 66, UCMJ, 10 U.S.C. $\S 866$.

4 See Denedo v. United States, 66 M.J. 114 (C.A.A.F. 2008) ("In addition to issues of law, the scope of review at the Court of Criminal Appeals extends to factual sufficiency and sentence appropriateness." (citing Article 66(c), UCMJ, 10 U.S.C. $\S$ 866(c)))

$5 \quad$ USCAAF Rule 5, 10 U.S.C. § 867(c).

6 See 28 U.S.C. $\S 1259$. See also USCAAF Cases Granted by the Supreme Court (Sept. 9, 2014) (on file with USCAAF) (list of USCAAF cases granted certiorari by the Supreme Court); O'Connor v. United States, 535 U.S. 1014 (2002) (vacating and remanding decision for reconsideration regarding recent precedent); Edmond v. United States, 520 U.S. 651 (1997) (reviewing appointment of civilians to military court under appointments clause); Carpenter v. United States, 515 U.S. 1138 (1995) (vacating and remanding decision for reconsid. eration regarding recent precedent); Denedo v. United States, 66 M.J. 114 (C.A.A.F. 2008) aff'd and remanded, 556 U.S. 904 (2009) (CAAF's ability to conduct coram nobis review); Gold. smith v. Clinton, 48 M.J. 84 (C.A.A.F. 1998) rev'd, 526 U.S. 529 (1999) and vacated, 52 M.J. 415 (C.A.A.F. 1999); United States v. Scheffer, 44 M.J. 442 (C.A.A.F. 1996) rev'd, 523 U.S. 303 (1998) (reviewing admission of polygraph evidence); United States v. Mobley, 44 M.J. 453 (C.A.A.F. 1996) cert. granted, judgment vacated, 523 U.S. 1056 (1998) (review of admission of polygraph examination); United States v. Edmond, 41 M.J. 419 (C.A.A.F. 1995) cert. granted, judgment vacated, 516 U.S. 802 (1995); United States v. Loving, 41 M.J. 213 (C.A.A.F. 1994) opinion modified on reconsideration, 42 M.J. 109 (C.A.A.F. 1995) and aff'd, 517 U.S. 748 (1996) (death sentence review); United States v. Ryder, 39 M.J. 454 (C.M.A. 1994) rev'd, 515 U.S. 177 (1995) (review of admitting testimony and evidence that defendant used illicit drugs); United States v. Davis, 36 M.J. 337 (C.M.A. 1993) aff'd, 512 U.S. 452 (1994) (affirming denial of motion to suppress); United States v. Carpenter, 37 M.J. 291 (C.M.A. 1993) cert. granted, judgment vacated, 515 U.S. 1138 (1995) (review of appointments clause); United States v. Weiss, 36 M.J. 224 (C.M.A. 1992) aff'd, 510 U.S. 163 (1994)

(appointments clause applies to military justice system); United States v. Jordan, 29 M.J. 177 (C.M.A. 1989) cert. granted, judgment vacated, 498 U.S. 1009 (1990) (holding that civilian counsel must contact witness's military counsel before obtaining a statement); United States v. Solorio, 21 M.J. 251 (C.M.A. 1986) aff'd, 483 U.S. 435 (1987) (affirming reversal of motion to dismiss); United States v. Goodson, 18 M.J. 243 (C.M.A. 1984) cert. granted, judgment vacated, 471 U.S. 1063 (1985) (finding that witness to a crime has a right to counsel).

7 Article 67(a), UCMJ, 10 U.S.C. § 867(a) (2012).

8 See United States v. Barraza-Martinez, 58 M.J. 173, 174 (C.A. A.F. 2003) (holding that it was not plain error for trial counsel to call the defendant a "traitor" in sentencing argument).

9 See United States v. Eslinger, 70 M.J. 193 (C.A.A.F. 2011) (ruling that evidence establishing the defendant's rehabilita. tive potential is permissible at sentencing).

10 See United States v. Talkington, 73 M.J. 212, 218 (C.A.A.F. 2014) (holding that accused may mention sex offender reg. istration in unsworn statement during sentencing).

11 See United States v. Mead, 72 M.J. 479, 479 (C.A.A.F. 2013) (defendant contesting military judge's calculation of sentence); United States v. Beaty, 70 M.J. 39, 44 (C.A.A.F. 2011) (reviewing maximum punishment authorized by an offense).

12 Goldsmith v. Clinton, 48 M.J. 84 (C.A.A.F. 1998), rev'd, 526 U.S. 529 (1999).

13 See Ex parte Quirin, 317 U.S. 1, 39.41 (1942) modified sub nom. U.S. ex rel. Quirin v. Cox, 63 S.Ct. 22 (1942).

14 See United States v. Care, 18 C.M.A. 535, 541, 40 C.M.R. 247, 253 (1969) (requiring "not only that the elements of each offense charged have been explained to the accused but also that the military trial judge [] has questioned the accused about what he did or did not do, and what he intended ... to make clear the basis for a determination by the military trial judge or president whether the acts or the omissions of the accused constitute the offense or offenses to which he is pleading guilty.")

15 See United States v. Winckelmann, 73 M.J. 11 (C.A.A.F. 2013); United States v. Moffeit, 63 M.J. 40 (C.A.A.F. 2006); United States v. Sales, 22 M.J. 305 (C.M.A. 1986).

16 See Winckelmann, 73 M.J. at 15 ("In members cases it is impossible to remand for a rehearing on sentence before the same court-martial that convicted the accused. 'A courtmartial has neither continuity nor situs and often sits to hear only a single case. Because of the nature of military service, the members of a court-martial may be scattered throughout the world within a short time after a trial is concluded.'" (citing Jackson v. Taylor, 353 U.S. 569, 579 (1957))).

17 Generally, the previous sentence approved by the convening authority serves as a limit on what sentence can later be approved following a rehearing. However, Rule for Courts. Martial 810(d)(2) provides,

If, after the earlier court-martial, the sentence was approved in accordance with a pretrial agreement and at the rehearing the accused fails to comply with the pretrial agreement...the approved sentence resulting at a rehearing of the affected charges and specifications may include any otherwise lawful punishment not in excess of or more severe than lawfully adjudged at the earlier court-martial.

18 See Annual Report Submitted to the Committees On Armed Services 52 (2013), available at http://www.armfor.uscourts. gov/newcaaf/annual/FY12AnnualReport.pdf.

19 Exercising unlawful Command Influence, defined in part as "attempt[ing] to coerce or, by any unauthorized means, influence the action of a court-martial or any other military tribunal or any member thereof," is prohibited under Article 37(a) of the UCMJ. As the Court of Military Appeals has noted, " "[c]ommand influence is the mortal enemy of military justice' and 'involves a corruption of the truth-seeking function of the trial process."' United States v. Gleason, 43 M.J. 69, 73 (C.A. A.F. 1995) (internal quotation marks omitted) (quoting United States v. Thomas, 22 M.J. 388, 393 (C.M.A. 1986)).

20 Top Five Offenses in Theater, U.S. Army Trial Judiciary, Office of the Clerk of Court (on file with author).

21 Dep't of the Army, Pam. 27.9, Legal Services, Military Judges' Benchbook, para. 2-5.21 (2010).

22 In the case of a dismissal of a commissioned officer, the dis. missal may not be executed until approved by the Secretary concerned. See R.C.M. 1206.

23 At the time the convening authority reviews the record of trial from a court-martial, he or she is required to also receive from the Staff Judge Advocate a recommendation or SJAR. Among other things, the SJAR may identify a legal error in the proceedings or a legally insufficient finding prompting a recom. mendation to dismiss a charge.

24 See Edward F. Sherman, The Civilianization of Military Law, 22 ME. L. REV. 3, 28 (1970). 
See United States v. Barner, 56 M.J. 131 (C.A.A.F. 2001) (multiplicity); United States v. Quiroz, 55 M.J. 334 (C.A.A.F. 2001) (unreasonable multiplication of charges); United States v. Lacy, 50 M.J. 286 (C.A.A.F. 1999) (sentence disparity). F. 2006); United States v. Harvey, 64 M.J. 13 (C.A.A.F. 2006); Toohey v. United States, 60 M.J. 100 (C.A.A.F. 2004); United States v. Oestmann, 61 M.J. 103 (C.A.A.F. 2005)

30 Army 2020: Generating Health \& Discipline in the Force Ahead of the Strategic Reset, 2011, p. 148.

31 See Denedo v. United States, 66 M.J. 114 (C.A.A.F. 2008), aff'd, 556 U.S. 904 (2009) (military courts have jurisdiction to consider petition for error coram nobis alleging ineffective assistance of counsel based on lawyer's failure to inform mil. itary defendant of collateral consequences regarding immi. gration status).

32 United States v. Talkington, 73 M.J. 212 (C.A.A.F. 2014).

33 See e.g., id. at 212 (finding that the Military Judge can instruct members to disregard collateral consequences when determining sentence); United States v. Riley, 72 M.J. 115 (C.A.A.F. 2013) (finding that an accused must know of collateral consequences before pleading guilty).

34 The corrections facility at Sembach Kaserne became fully operational in December 2014, and replaced the facility that previously operated in Mannheim, Germany. See U.S. Army, Sembach confinement facility, another European infrastructure consolidation milestone (Dec. 17, 2014), available at http:// www.army.mil/article/140198.

35 See generally Dep't of Defense (DOD) Instruction 1325.07, Administration of Military Correctional Facilities and Clemency and Parole Authority 12 (Mar. 11, 2013) ("Male and female prisoners may be confined in the same [military confinement facility]. The sleeping and personal hygiene areas for male and female prisoners shall be separate."). See also Command
Information, Naval Consolidated Brig Miramar, U.S. Navy, available at http://www.public.navy.mil/bupers-npc/support/ correctionprograms/brigs/miramar/Pages/default.aspx. DOD Instruction 1325.07 p. 7, March 11, 2013. DOD Instruction 1325.07 p. 7-8, March 11, 2013.

38 Id.

39 Prisoners fear being "fed-exed"-the term used to describe being transferred from the military prison system to a BOP prison. Jonathan Allen, Monotonous, rigid military prison life awaits Manning, Reuters (Aug. 4, 2013), available at http:// www.reuters.com/article/2013/08/04/us-usa-wikileaks. manning.prison-idUSBRE97304F20130804.

40 See Nathan James, The Federal Prison Population Buildup: Overview, Policy Changes, Issues, and Options, Congressional Research Service (April 15, 2014), available at http://fas.org/ sgp/crs/misc/R42937.pdf.

41 U.S. v. McNutt, 62 M.J. 16, 19-20 (C.A.A.F. 2005).

42 See United States v. McPherson, 73 M.J. 393, 399 (C.A.A.F. 2014) (Baker, J., concurring in part and dissenting in part).

43 See generally id.

44 American Bar Association, Adolescence, Brain Development, and Legal Culpability (January 2004), available at http:// www.americanbar.org/content/dam/aba/publishing/criminal_justice_section_newsletter/crimjust_juvjus_Adolescence. authcheckdam.pdf.

45 J. Douglas Bremmer, Traumatic stress: effects on the brain, Dialogues in Clinical Neuroscience, 445-61 (Dec. 2006); see also Kate Wenner, War is Brain-Damaging, N.Y. Times, Mar. 17, 2012, available at http://www.nytimes.com/2012/03/18/ opinion/sunday/war-is-brain-damaging.html.

46 Roper v. Simmons, 543 U.S. 551 (2005).

47 Graham v. Florida, 560 U.S. 48 (2010).

48 Roper, 543 U.S. at 567 (quoting Atkins v. Virginia, 536 U.S. 304, 316 (2002))

49 Graham, 560 U.S. at 71-72.

50 Miller v. Alabama, 132 S.Ct. 2455, 2458 (2012).

51 Id. at 2464. 